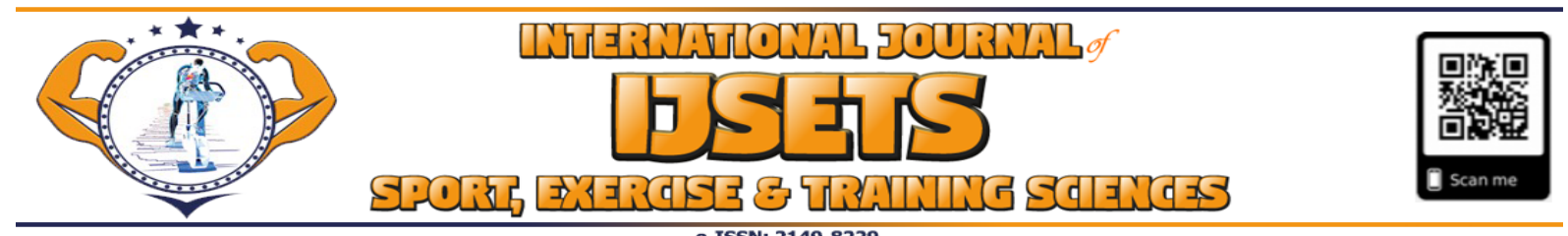

http://dergipark.gov.tr/useeabd

\title{
The Effect of Aerobic Exercise on Pulmonary Function and Aerobic Capacity in Sedentary Men
}

\section{Gamze İŞLEYEN ${ }^{1}$, Önder DAĞLIOĞLU²}

\begin{tabular}{|c|c|}
\hline Abstract & Keywords \\
\hline $\begin{array}{l}\text { Aim: The purpose of this study is to examine the effect of an } 8 \text {-week aerobic exercise program on the } \\
\text { respiratory function and aerobic capacity of sedentary men. }\end{array}$ & $\begin{array}{r}\text { Aerobic Exercise, } \\
\text { Respiratory Functions, }\end{array}$ \\
\hline $\begin{array}{l}\text { Methods: A total of } 24 \text { male sedentary individuals between } 18-23 \text { years who were living in the Gaziantep, } \\
\text { participated in the present study voluntarily. Participants were randomly divided into two groups as } \\
\text { experimental group ( } \mathrm{n}=12 \text {, age: } 21.86 \pm 2.78 \text { years) and control group ( } \mathrm{n}=12 \text {, age: } 22.51 \pm 2.32 \text { years). The } \\
\text { experimental group participated in the aerobic exercise program for three days per week for eight weeks. No } \\
\text { exercise program was administered to the control group. Before and after the exercise program, body weight } \\
\text { (BW), body mass index (BMI), body fat percentage (BFP), resting heart rate (RHR), maximal oxygen } \\
\text { consumption (VO } \mathrm{V}_{2} \text { max), vital capacity (VC), forced vital capacity (FVC), forced expiratory volume (FEV1), } \\
\text { forced expiratory rate (FEV1/FVC \%) and maximal voluntary ventilation (MVV) measurements were } \\
\text { performed. Respiratory parameters were measured with the M.E.C. The Pocket Spiro USB-100 device. The } \\
\mathrm{VO}_{2} \text { max was measured with the MEC PFT ergo-spirometer system. Body weight and height were measured } \\
\text { using the N.A.N. device. Paired Sample t test was used for intra-group comparison and Independent Sample } \\
\text { t test was used for inter-group comparison for statistical analysis of the data. The level of significance was } \\
\text { determined as }<0.05 \text {. }\end{array}$ & $\begin{array}{r}\mathrm{VO}_{2} \max \\
\text { Sedentary, }\end{array}$ \\
\hline $\begin{array}{l}\text { Results: There were statistically significant improvements }(\mathrm{p}<0.05) \text { in the } \mathrm{BW}, \mathrm{BMI}, \mathrm{BFP}, \mathrm{RHR}, \mathrm{VO}_{2} \max \text {, } \\
\mathrm{VC}, \mathrm{FVC}, \mathrm{FEV} 1 \text {, FEV1/FVC } \% \text { and MVV values of the experimental group. The weight and BMI values of } \\
\text { the control group were found significant }(\mathrm{p}<0.05) \text {. There was no significance in the other data. There were }\end{array}$ & Received: $\frac{\text { Article Info }}{23.08 .2020}$ \\
\hline statistically significant differences between the groups in favor of the experimental group, in the assessments & Accepted:18.09.2020 \\
\hline of BMI, BFP, RHR, $\mathrm{VO}_{2} \max , \mathrm{VC}, \mathrm{FVC}, \mathrm{FEV} 1, \mathrm{FEV} 1 / \mathrm{FVC} \%$ and $\mathrm{MVV}$ values $(\mathrm{p}<0.05)$ & Online Published:18.09.2020 \\
\hline $\begin{array}{l}\text { Conclusion: As a result, it is considered that the aerobic exercise program which was applied to the } \\
\text { sedentary individuals has a positive effect on the respiratory functions and aerobic capacity values. It can be } \\
\text { said that regular and planned aerobic exercises will affect respiratory functions and aerobic capacity } \\
\text { positively. }\end{array}$ & DOI: $10.18826 / \mathrm{u}$ \\
\hline
\end{tabular}

\section{INTRODUCTION}

Recently with the development of technology people have become a sedentary lifestyle maintains. The advances in technology limit the duration of physical activity in people's daily lives. Sedentary life and inactivity cause many health problems. Therefore, it is necessary to start the habit of exercising and doing sports at an early age (Çelebi, 2008). The need to do physical activity and exercise in order to get rid of the negative effects of sedentary life and to keep the organism healthy and fit occurs as a necessity (Arcury et al., 2006).

Physical activity and exercise are important for general health and quality of life. It is important for adults to exercise moderate intensity for at least 30 minutes a few days a week to avoid the negative effects of sedentary life (Bauman, 2004).

Regular and planned exercises will increase the strength and respiratory volume of the respiratory muscles. Endurance training is important in cellular adaptations of respiratory muscles and respiratory system (Taşgın \& Dönmez, 2009). The functional status of the respiratory system can conventionally be determined by measuring lung volumes and capacities. Changes in respiratory volume and frequency occur with physical activity. Aerobic exercises; It is one of the exercise types in which large muscle groups participate continuously and rhythmically. Aerobic exercise helps to improve the athlete's oxygen system (Ardiç, 2014). Aerobic capacity $\left(\mathrm{VO}_{2} \max \right)$ is defined as the maximum amount of oxygen available to the muscles in a voluntary physical activity (Howley, Bassett \&Welch, 1995; Bassett \& Howley, 2000). Aerobic based exercises are likely to be considered as one of the foundations of quality and healthy life. Exercise programs in accordance with the purpose of a quality and healthy life is achieved. This study is important for the relationship between submaximal aerobic exercise and exercise

The role and contributions of each authors as in the section of IJSETS Writing Rules "Criteria for Authorship" is reported that: 1. Author: Contributions to the conception or design of the paper, data collection, writing of the paper and final approval of the version to be published paper; 2. Author: Data collection, preparation of the paper according to rules of the journal, final approval of the version to be published paper;

${ }^{1}$ Faculty of Sports Sciences, Gaziantep University, Gaziantep/Turkey, ORCID ID: 0000-0002-2468-7906, gmz.isleyen@gmail.com

${ }^{2}$ Faculty of Sports Sciences, Gaziantep University, gaziantep/Turkey, ORCID ID: 0000-0002-6213-9855, daglioglu@gantep.edu.tr 
protocols, respiratory functions and aerobic capacity, and development of exercise programs for sedentaries.

The aim of this study is to reveal the effect of aerobic exercise program on respiratory functions and aerobic capacity in sedentary men and to make recommendations for the creation of aerobic based exercise programs for individuals with sedentary life.

\section{METHOD}

\section{Participants}

A total of 24 male sedentary individuals aged 18-23 years participated in this study voluntarily. The participants were randomly divided into two groups as experimental group ( $\mathrm{n}=12$, age: $21.86 \pm 2.78)$ and control group ( $\mathrm{n}=12$, age: $22.51 \pm 2.32$ ). The experimental group participated in aerobic exercise program 3 days a week for 8 weeks. No exercise program was applied to the control group.

Ethics Committee approval of this study was obtained from Gaziantep University Clinical Research Ethics Committee (Protocol no: 2017/117).

Research Protocol: The aerobic exercise program was applied to the experimental group 3 times a week for 8 weeks. Before and after exercise body weight (BW), body mass index (BMI), body fat percentage (BFP), resting heart rate (RHR), Maximal oxygen consumption $\left(\mathrm{VO}_{2} \mathrm{max}\right)$, vital capacity (VC), forced vital capacity (FVC), forced expiratory volume (FEV1), forced expiratory rate (FEV1/FVC \%) and maximum voluntary ventilation (MVV) were measured. Respiratory parameter measurements were realized by using M.E.C. Pocket Spiro USB-100 device. Body weight and height measurements N.A.N. brand device was used.

Aerobic Exercise Program: The $\operatorname{maxVO}_{2}$ values of the experimental and control groups participated in our study were found by using MEC PFT SYSTEMS ERGO model gas analysis system. $70 \%$ of $\mathrm{VO}_{2}$ max score for all subjects was found using Wasserman graph In the experimental group, 20 minutes of aerobic exercise program was applied 3 days a week for 8 weeks according to the heart rate of $70 \%$ of $\mathrm{VO}_{2}$ max. The subjects were warm up for 10 minutes before training and then cool down period for 5 minutes. The Polar ${ }^{\circledR}$ S810i pulse meter was used to control the heart rate of $\mathrm{VO}_{2} \max (70 \%)$ for each individual during training.

\section{Data Collection}

Anthropometric Measurements: Body weights and lengths were measured by N.A.N brand measuring device. The subjects participated in the measurements with shorts, t-shirt and bare feet and their height was recorded in $\mathrm{cm}$ and body weight in $\mathrm{kg}$. BMI measurements were found by dividing the height of the square meter in terms of body weight (Fox et al., 1999).

$V_{\mathrm{O}_{2}} \boldsymbol{m a x}$ Measurement Protocol: MEC PFT SYSTEMS ERGO model gas analysis system was used on the electro magnetic bicycle ergometer to measure $\mathrm{VO}_{2} \max$ values of the participants. Ramp protocol was applied in gradually increasing exercise test. During the Ramp protocol, subjects were stable for 3 minutes of baseline gas changes. They then switched to 3 minutes no-load pedals (warm-up). The test protocol, which started at 25 watts, increased by 25 watts per minute and continued until the subject was unable to tolerate the load level and quit the test. It was noted that the pedaling cycle was about 50-60 $\mathrm{rpm}$ per minute. At the end of the test, the pedal load was reduced to 25 watts and the pedal was turned on for another 3 minutes. $\mathrm{VO}_{2} \max$ and $\mathrm{VO}_{2} \max (70 \%)$ values were determined by MEC software and Wasserman graphics (ATS/ACCP, 2003).

Body Fat Percentage (\%): Body fat percentage of subjects was measured using Bioelectrical Impedance Analysis Method (BIA) (Tanita Body Composition Analyzer model BC-418) technique (Ellis et al., 1999).

Measurement of Resting Heart Rate: Resting heart rate was measured using a digital automatic blood pressure monitor (Omron, M6 Comfort, Omrom Healthcare Co., Ltd. Kyoto, Japan). Two measurements were taken and their mean values were recorded.

Measurement of Respiratory Parameters: Respiratory parameters M.E.C. Pocket Spiro USB-100 model was measured. During the measurement, the subject was allowed to wear sports clothes. The subjects were informed about the measurement. It was said that a maximal effort was required for the measurement results to be accurate. Measurements were taken while the subject was sitting. A separate mouthpiece was used for each individual. The nose of the subject was closed with a plug and the 
mouthpiece was used in such a way that there was no gap in the rim. During the measurement, the subject was audibly motivated.

VC measurement: The subject was stimulated three times with normal ventilation, followed by a maximal inspiration of filling the lungs with air, and then expiration of all air in the lung slowly (Günay et al., 2010).

FVC measurement: During the test, the subject completed three normal breathing cycles, followed by rapid and deep expiration after a deep and strong maximal inspiration. FEV1 and FEV1/FVC \% values were obtained with this test (Miller et al., 2005).

MVV measurement: The subject completed the measurement with maximal fast and deep breathing for 12 seconds with the command (Wanger et al., 2005).

\section{Statistical analysis}

Statistical analysis of this research was performed with the help of SPSS statistical program (SPSS for Windows, version 16.0, SPSS Inc. Chicago, Illinois, USA). Mean and standard deviation values were used as descriptive statistics. Prior to statistical procedures, Shapiro-Wilk test was used to determine whether the data were normally distributed and homogeneous. Independent Samples T Test was used to evaluate the significance between the experimental and control groups. Paired Samples T Test was used for intra-group comparisons. Statistical values were analyzed at $\mathrm{p}<0.05$ significance level.

\section{RESULTS}

Table 1. Pre-test and post-test analysis results of the experimental group

\begin{tabular}{|c|c|c|c|}
\hline Variable & $\begin{array}{c}\text { Pre-test (n:12) } \\
\bar{X} \pm \text { SD }\end{array}$ & $\begin{array}{c}\text { Post-test (n:12) } \\
\bar{X} \pm \text { SD }\end{array}$ & $\mathbf{p}$ \\
\hline$\overline{\text { Age (year) }}$ & $21.86 \pm 2.78$ & $21.86 \pm 2.78$ & - \\
\hline Height $(\mathrm{cm})$ & $175.6 \pm 2.47$ & $175.6 \pm 2.47$ & - \\
\hline Weight (kg) & $75.62 \pm 2.16$ & $73.26 \pm 3.24$ & $0.001 *$ \\
\hline BMI $\left(\mathrm{kg} / \mathrm{m}^{2}\right)$ & $24.23 \pm 2.52$ & $23.25 \pm 2.53$ & $0.002 *$ \\
\hline $\mathrm{BFP}(\%)$ & $14.56 \pm 2.56$ & $12.11 \pm 1.52$ & $0.001 *$ \\
\hline RHR (beat/min) & $77.23 \pm 2.61$ & $74.12 \pm 3.46$ & $0.001 *$ \\
\hline VC (lt) & $6.12 \pm 1.56$ & $7.26 \pm 2.56$ & $0.001 *$ \\
\hline FVC (lt) & $5.41 \pm 2.63$ & $7.45 \pm 5.22$ & $0.022 *$ \\
\hline FEV1 (lt) & $4.55 \pm 4.23$ & $5.68 \pm 2.24$ & $0.013 *$ \\
\hline FEV1/FVC (\%) & $97.05 \pm 4.06$ & $98.97 \pm 4.71$ & $0.001 *$ \\
\hline MVV (breaths/min) & $145.12 \pm 8.12$ & $155.25 \pm 9.52$ & $0.001 *$ \\
\hline $\mathrm{VO}_{2} \max (\mathrm{ml} / \mathrm{kg} / \mathrm{min})$ & $38.21 \pm 1.54$ & $40.38 \pm 1.99$ & 0.001* \\
\hline
\end{tabular}

In Table 1, the comparison of the pre-test and post-test results of the data obtained after the aerobic exercise program applied to the experimental group is given. In the experimental group, weight, BMI, BFP, RHR, $\mathrm{VO}_{2} \max , \mathrm{VC}, \mathrm{FVC}, \mathrm{FEV} 1, \mathrm{FEV} 1 / \mathrm{FVC} \%$ and MVV values were significant $(\mathrm{p}<0.05)$.

Table 2. Pre-test and post-test analysis results of the control group

\begin{tabular}{|c|c|c|c|}
\hline Variable & $\begin{array}{c}\text { Pre-test (n:12) } \\
\bar{X} \pm S D\end{array}$ & $\begin{array}{c}\text { Post-test (n:12) } \\
\bar{X} \pm S D\end{array}$ & $\mathbf{p}$ \\
\hline Age (year) & $22.51 \pm 2.32$ & $22.51 \pm 2.32$ & - \\
\hline Height $(\mathrm{cm})$ & $177.41 \pm 2.89$ & $177.41 \pm 2.89$ & - \\
\hline Weight $(\mathrm{kg})$ & $78.19 \pm 2.12$ & $77.11 \pm 2.10$ & 0.041* \\
\hline BMI $\left(\mathrm{kg} / \mathrm{m}^{2}\right)$ & $24.89 \pm 1.08$ & $24.53 \pm 1.04$ & 0.704 \\
\hline BFP $(\%)$ & $15.54 \pm 1.22$ & $14.57 \pm 1.41$ & $0.044 *$ \\
\hline RHR (beat/min) & $72.59 \pm 0.42$ & $72.12 \pm 0.89$ & 0.125 \\
\hline $\mathrm{VC}(1 \mathrm{t})$ & $4.96 \pm 0.93$ & $4.98 \pm 0.21$ & 0.262 \\
\hline $\mathrm{FVC}(\mathrm{lt})$ & $4.32 \pm 0.45$ & $4.48 \pm 0.97$ & 0.122 \\
\hline FEV1 (lt) & $4.48 \pm 0.53$ & $4.55 \pm 1.93$ & 0.452 \\
\hline FEV1/FVC $(\%)$ & $93.38 \pm 3.56$ & $93.68 \pm 3.21$ & 0.251 \\
\hline MVV (breaths/min) & $141.37 \pm 8.29$ & $142.22 \pm 9.69$ & 0.322 \\
\hline $\mathrm{VO}_{2} \max (\mathrm{ml} / \mathrm{kg} / \mathrm{min})$ & $39.56 \pm 2.67$ & $39.69 \pm 2.99$ & 0.253 \\
\hline
\end{tabular}


Table 2 shows the comparison of pre-test and post-test results of the control group. The weight and BFP values of the control group were significant $(p<0.05)$. Other data were not significant.

Table 3. Comparison of the experimental and control groups

\begin{tabular}{|c|c|c|c|}
\hline Variable & $\begin{array}{c}\text { Experimental Group Difference } \\
\bar{X} \pm \text { SD }\end{array}$ & $\begin{array}{c}\text { Control Group Difference } \\
\qquad \bar{X} \pm \text { SD }\end{array}$ & $\mathbf{p}$ \\
\hline Weight (kg) & $2.36 \pm 2.19$ & $1.08 \pm 1.22$ & $0.001 *$ \\
\hline BMI $\left(\mathrm{kg} / \mathrm{m}^{2}\right)$ & $0.98 \pm 0.44$ & $0.36 \pm 0.35$ & $0.002 *$ \\
\hline BFP $(\%)$ & $2.45 \pm 1.57$ & $0.97 \pm 0.79$ & $0.001 *$ \\
\hline RHR (beat/min) & $3.11 \pm 0.82$ & $0.47 \pm 0.29$ & 0.001* \\
\hline $\mathrm{VC}(\mathrm{lt})$ & $-1.14 \pm 1.45$ & $-0.02 \pm 0.34$ & 0.001* \\
\hline FVC (lt) & $-2.04 \pm 2.45$ & $-0.16 \pm 1.56$ & $0.001 *$ \\
\hline FEV1 (lt) & $-1.13 \pm 2.25$ & $-0.07 \pm 0.59$ & 0.001* \\
\hline FEV1/FVC (\%) & $-1.92 \pm 2.12$ & $-0.30 \pm 0.47$ & $0.001 *$ \\
\hline MVV (breaths/min) & $-10.13 \pm 3.45$ & $-0.85 \pm 0.94$ & 0.001* \\
\hline $\mathrm{VO}_{2} \max (\mathrm{ml} / \mathrm{kg} / \mathrm{min})$ & $-2.17 \pm 2.13$ & $-0.13 \pm 1.52$ & 0.001* \\
\hline
\end{tabular}

The comparison of the values of the experimental and control groups and the statistical results are shown in Table 3. There was a statistically significant difference between the groups in favor of the experimental group in weight, BMI, BFP, RHR, $\mathrm{VO}_{2} \max , \mathrm{VC}, \mathrm{FVC}, \mathrm{FEV} 1, \mathrm{FEV} 1 / \mathrm{FVC} \%$ and MVV values $(\mathrm{p}<0.05)$.

\section{DISCUSSION}

Physical and physiological characteristics of the organism improve with regular and planned aerobic training. However, regular aerobic exercise has been shown to have a positive effect on body composition. (Daglioglu et al., 2009; Eroglu \& Daglioglu, 2013; Heyward \& Stolarcyk, 1996).

In our study, the weight, BMI, BFP and RHR values of the 8-week aerobic exercise program were statistically significant $(p<0.05)$. In the control group, weight and BFP values were found to be significant at the end of the tests $(\mathrm{p}<0.05)$. Other data were not significant. In the comparison between the groups, all the data were statistically significant in favor of the experimental group $(p<0.05)$.

Szmedra et al., (1998) found a statistically significant decrease in the body weight of individuals as a result of 6-week treadmill exercise in their study. In another study, it was found that male university students who do regular sports 3 days a week have lower values of BFP and BMI than those who do not do regular sports (Karakaş et al., 2005). In another study, the BMI values of the experimental group were found to be 21.93 and the BMI values of the control group were found to be 22.73 in the regular strength exercises study (Eylen et al., 2017). Kandeydi (1994) found a decrease in BFP values in individuals who received regular swimming training. There are many studies showing that regular and planned physical activities reduce body fat percentage (Nar et al., 2013; Daglioglu, 2013a; Inan \& Daglioglu, 2013; Gücenmez et al., 2017; Ince \& Daglioglu, 2018).

In our study, the decrease in weight, BMI and BFP values of the experimental group was higher than the control group. This is thought to be due to the decrease in body fat percentage and the increase in body muscle mass due to the effect of aerobic training. The results in the literature are in parallel with the results of our research.

Daglioglu (2013a) in his study on young male individuals found a high decrease in RHR values after 8 weeks of submaximal erobic exercise. In another study, RHR values were decreased after 8 weeks of aerobic training program applied to university male students. In the control group, no significant difference was obtained (Yüksel, 2003). In the literature, as a result of aerobic training program applied in many studies, RHR values decrease (Gücenmez et al., 2017; Ozdal et al., 2013).

In our study, a significant decrease in RHR values of the experimental group was obtained. The decrease in RHR value in the experimental group is thought to be due to hypertrophy in the left ventricle of the heart. The results in the literature are similar to the results of our study.

Respiratory Parameters: In our study, statistically significant difference was found in VC, FVC, FEV1, FEV1/FVC \% and MVV values after 8 weeks of aerobic exercise program applied to the experimental group $(\mathrm{p}<0.05)$. No significant difference was found in the respiratory parameters of the control group. 
Statistically significant difference was found between VC, FVC, FEV1, FEV1/FVC \% and MVV values in favor of experimental group $(\mathrm{p}<0.05)$.

During physical activity, the muscles need more $\mathrm{O}_{2}$. In this way, a synchronous occurs in the respiratory system. Respiratory functions depend on the type of physical activity performed, the condition of the respiratory muscles, the enlargement of the lungs, and the flexibility of the bronchi and bronchi (Gözü et al., 1988). Vital capacity and forced vital capacity, which are pulmonary functions, are interpreted as normal by $80 \%$ and upper of the expected value for each individual according to age, height, gender and body weight (Weinberger \& Drazen, 1998). FEV1 value under $80 \%$ points an anormality in expiration (Tamer, 1995). Doherty \& Dimitrio (2007) examined the VC, FVC, FEV1 values of athletes and sedentary individuals and found that the athlete group values were higher than the control group. In another study, it was found that $\mathrm{VC}$ values of individuals doing regular sports were higher than sedentaries (Kandeydi \& Ergen 1982). Gupta \& Sawane (2012), in his study compared individuals doing swimming and yoga and found that swimming exercises showed better improvement in FVC values. In a study conducted, an increase in the FEV1\% of the field hockey players was found after 8 weeks of aerobic training program (Ozdal et al., 2013). Pherwani et al., (1989) swimmers VC, FVC, FEV1 values were found to be higher than the control group. In many studies in the literature, respiratory parameters were compared between sedentary and regular athletes and generally positive results were obtained in favor of athletes. It has been shown in many studies that respiratory functions parameters can be improved with regular training (Bağıran et al., 2019; Daglioglu, 2013b; Kalkan \& Daglioglu, 2018; Yilmaz \& Daglioglu, 2018).

Respiratory function values obtained in our study are in parallel with similar studies found in the literature. In our study, it was found that the 8-week aerobic exercise program applied to sedentary men had a positive effect on the respiratory parameters of the experimental group. This can be said to be due to the increase in respiratory volume, strengthening of the diaphragm muscles and the development of lung capacity due to the effect of aerobic exercise.

Aerobic Capacity: In this study, after the 8-week aerobic exercise program applied to sedentary male subjects, $\mathrm{VO}_{2}$ max parameters were statistically significant in the experimental group $(\mathrm{p}<0.05)$. The $\mathrm{VO}_{2} \mathrm{max}$ value of the control group was not significant ( $\mathrm{p}>0.05$ ). There was no significant difference in the other data $(\mathrm{p}>0.05)$. In the comparison between the groups, $\mathrm{VO}_{2} \max$ values were found significant in favor of the experimental group $(\mathrm{p}<0.05)$.

$\mathrm{VO}_{2}$ max plays an important role in increasing sporting performance during long and severe physical activities (Saltin, 2007). Regular and planned aerobic exercises increase $\mathrm{VO}_{2} \mathrm{max}$. This increase in $\mathrm{VO}_{2} \mathrm{max}$ is between 11-56 \% (Porcari et al., 1987). Rowland \& Boyajian (1995), 3 days a week 30 minutes of aerobic exercise program was found to increase significantly in the experimental group compared to the control group. In another study, $\operatorname{maxVO}_{2}$ values of sedentary men were found to be $42.58 \pm 2.85 \mathrm{ml} / \mathrm{kg} / \mathrm{min}$ (Daglioglu, Sirmen, \& Bostanc1, 2013). Williams \& Morton (1986) reported a significant increase in $\mathrm{VO}_{2}$ max values after a 12-week aerobic training program. Szmedra et al., (1998) 50 minutes of three-week exercises stated that the increase in $\mathrm{VO}_{2}$ max values. Kravitz et al., (1993) found that the step program with 8-week weights caused an increase in maximal oxygen consumption. In a study by Utter et al., (2000), they recorded an increase in $\mathrm{VO}_{2}$ max values in obese subjects after a 12-week submaximal level aerobic training program. $\mathrm{VO}_{2}$ max values obtained in our study are similar to the literature.

The general opinion in the literature is that $\mathrm{VO}_{2} \mathrm{max}$ increases as a result of exercises and trainings. In this study, the experimental group achieved a greater workload and higher $\mathrm{VO}_{2}$ max levels by maintaining cardiopulmonary exercise test longer than the control group. Inotherwords, the aerobic capacity of the experimental group is more advanced than the control group.

\section{CONCLUSION}

In conclusion, it can be said that the 8-week aerobic exercise program applied to sedentary men positively affects respiratory functions and aerobic capacity values. Sedentary individuals may be offered regular aerobic exercise programs with a well-defined duration, severity and frequency to improve quality of life and to maintain respiratory and cardiovascular health. 


\section{PRACTICAL APPLICATION}

Regular and planned aerobic based exercise programs may be suggested to improve the health and quality of life of individuals and the negative effects of sedentary lifestyle on sedentaries.

\section{ACKNOWLEDGEMENTS}

This study is a part of Gamze Isleyen's master thesis. We thank our Department of Physical Education and Sport in University of Gaziantep for their support in our study.

\section{REFERENCES}

American Thoracic Society American College of Chest Physicians (ATS/ACCP). (2003). Am J Respir Crit Care Med., 167, 211-277.

Arcury, T. A., Snively, B. M., Bell, R. A., Smith, S. L., Stafford, J. M., Arkader, W. L., \& Quandt S. A. (2006). Physical activity among rural older adults with diabetes. J Rural Health, 22(2), 164-168.

Ardıç, F. (2014). Egzersiz reçetesi. Türkiye Fiziksel Tip ve Rehabilitasyon Dergisi, 60, 1-8.

Bağıran, Y., Dağlığlu, Ö., \& Bostancı, Ö. (2019). The effect of respiratory muscle training on aerobic power and respiratory parameters in swimmers. International Journal of Sport Exercise and Training Sciences-IJSETS, 5 (4), 214-220.

Bassett, D. R., \& Howley, E. T. (2000). Limiting factors for maximum oxygen uptake and determinants of endurance performance. Med, Sci, Sports Exerc., 32(1), 70-84.

Bauman, A. E. (2004). Updating the Evidence that Physical Activity is Good for Health: An Epidemiological Review 2000-2003. Journal of Science and Medicine in Sport, 7(1), 6-19.

Çelebi, Ş. (2008). Yüzme Antrenmanı Yaptırılan 9-13 yaş Grubu İlköğretim Öğrencilerinde Vücut Yapısal ve Fonksiyonel Özelliklerinin İncelenmesi, Erciyes Üniversitesi Sağllk Bilimleri Enstitüsü, Beden Eğitimi ve Spor A.B.D, Kayseri.

Daglioglu, O. (2013a). The effect of 8-week submaximal aerobic exercise on cardiovascular parameters and body composition in young men. International Journal of Academic Research, 5(4), 210-216.

Daglioglu, O. (2013b). The effect of gradually increasing exercise on oxygen consumption and lactate levels in swimmers. Annals of Biological Research, 4(10), 96-102.

Daglioglu, O., Sirmen, B., \& Bostanci, O. (2013). The Effect of Aerobic Exercise on Oxidative Stress in Elite Swimmers and Sedentaries and the Investigation of Pon1 Gene Polymorphism. International Journal of Basic Sciences \& Applied Research, 2(6), 548-555.

Daglioglu, O., Cavas, L., Hazar, M., Gurler, S., Cavas, B., \& Yurdakoc, K. (2009). A Comparative Study: Skin Folds, Estimated Percentage Body Fat, Total Body Fat Weight And Fat-Free Body Mass in The Female And Male Turkısh Athletes, e-Journal of New World Sciences Academy Sports Sciences, 4(4), 334-340.

Doherty, M., \& Dimitriou, L. (2007) Comparison of lung volume in Greek swimmers, land based athletes, and sedentary controls using allometrics caling. Br J Sports Med, 31(4), 337-41.

Ellis, K. J., Bell, S. J., Chertow, G. M., Chumlea, C. W., Knox, T. A., Kotler, P. D., Lukaski, H.C., \& Schoeller, D. A. (1999). Bioelectical impedance methods in clinical research: a follow-up to the NIH tecnology assesment confererence. Nutrition, 15, 874-80.

Eroglu, Y., \& Daglioglu, O. (2013). The effect of submaximal exercise on oxidant and antioxidant mechanisms in judokas and sedentary. International Journal of Sport Studies, 3(5), 480-486.

Eylen, M. A., Daglioglu, O., \& Gucenmez, E. (2017). The Effects of Different Strength Training on Static and Dynamic Balance Ability of Volleyball Players. Journal of Education and Training Studies, 5(13), 13-18.

Fox, E. L., Bowers, R. W., \& Foss, M. L. (1999). Beden Eğitimi ve Sporun Fizyolojik Temelleri, Bağırgan Yayımevi, (çev:Cerit, M.), Ankara.

Gözü, R. D., Liman, E., \& Kan, İ. (1988). Thoraks ölçümleri ve solunum fonksiyonlarının antrenmanlarla değişimi. Spor Hekimliği Dergisi, 23 (1), 1-8.

Gücenmez, E., Dağlığlu, Ö., \& Dağlıoğlu, T. (2017). The Effect of Aerobic Exercise on Oxygen 
Consumption Capacities and Body Composition in Football Players. Atabesbd, 19(4), 136-147.

Günay, M., Tamer, K., \& Cicioğlu, İ. (2010). Spor Fizyolojisi ve Performans Ölçümü, 2. Baskı. Cicioğlu İ (Ed) Gazi Kitabevi, Ankara, 2, 172-567.

Gupta, S. S., \& Sawane, M. V. (2012). A comparative study of the effects of yoga and swimming on pulmonary functions in sedentary subjects. Int $J$ Yoga, 5(2), 128-33.

Heyward, V. H., \& Stolarcyk, L. M. (1996). Body Composition Assesment. Human Kinetics, 1, 21-44, USA.

Howley, E. T., Bassett, D. R., \& Welch, H. G. (1995). Criteria for maximal oxygen uptake: review and commentary. Med Sci Sports Exerc., 27(9), 1292-1301.

Inan, B., \& Daglioglu, O. (2013). Examination of children's body composition and biomotoric features which attended summer football schools. Turkish Journal of Sport and Exercise, 15(2), 80-87.

Ince, T., \& Daglioglu, O. (2018). The Effect of The Plyometric Training Program on Sportive Performance Parameters in Young Soccer Players. Turkish Journal of Sport and Exercise, 20(3), 184-190.

Kalkan, M.K., \& Daglioglu, O. (2018). The Effects of 8-Week Aerobic Training Program on Respiratory and Circulatory Parameters of Female Swimmers between 12-14 Years Old. Journal of Education and Training Studies, 6(12), 202-207.

Kandeydi, H., \& Ergen, E. (1982). Beden Eğitimi ve Spor Yüksekokulu Öörencileri ile T1p Öğrencilerinin Fizyolojik ve Fonksiyonel Özelliklerinin Karşılaştırılması, Spor Hekimleri Dergisi, 59.

Kandeydi, O. (1994). Düzenli Yüzme Antrenmanı Yapan Üniversite Öğrencilerinde Görülen Fizyolojik Değişiklikler, Yüksek Lisans Tezi, İzmir.

Karakaş, S., Taşer, F., Yıldız, Y., \& Köse, H. (2005). Tip Fakültesi ve Spor Yüksek Okulu Ögrencilerinde Biyoelektriksel İmpedans Analizi (BIA) Yöntemi ile Vücut Kompozisyonlarının Karş1laştırılması, ADÜ Tip Fakültesi Dergisi, 6(3), 5-9.

Kravitz, L., Cisar, J. C., Setterlund, S. J. (1993).The physiological effects of step training with and without hand weighs, Journal of Sports Medicine and Physical Fitness, 33(4), 348-358.

Miller, M.R., Crapo, R., Hankinson, J., Brusasco, V., Burgos, F., Casaburi, R., Coates, A., Enright, P., Grinten, P. M., Gustafsson, P., et al. (2005). General considerations for lung function testing. Eur Respir J, 26, 153-161.

Nar, D., Daglioglu, O., \& Kaya F. (2013). The investigation of the effects of 3-month fitness applications on body compositions in sedentaries. International Journal of Sport Studies, 3(8), 836-846.

Ozdal, M., Daglioglu, O., \& Demir, T. (2013). Effect of aerobic training program on some circulatory and respiratory parameters of field hockey players. International Journal of Academic Research, 5(4), 97-103.

Pherwani, A.V., Desai, A. G., \& Solepure, A. B. (1989). A study of pulmonary function of competitive swimmers. Indian J Physiol Pharmacol, 33(4), 228-32.

Porcari, J., McCarron, R., Kline, G., Freedson, P.S., Ward, A., Ross, J. A., \& Rippe, J. M. (1987). Is Fast Walking an Adequate Aerobic Training Stimulus for 30- to 69-Year-Old Men and Women?, The Physician and Sportsmedicine, 15(2), 119-129.

Rowland, T. W., \& Boyajian, A. (1995). Aerobik Response To Endurance Exercise Training In Children. 96 (4 Pt 1), 654 -658.

Saltin, B. (2007). Training for anaerobic and aerobic power. In McArdle WD, Katch FI, Katch VL, (eds.). Exercise physiology Energy, Nutrition \& Human Performance (6th ed.) Baltimore: Lippincott Williams \& Wilkins, 469-508.

Szmedra, L., Lemura, L. M., \& Shearn, W. M. (1998). Exercise Tolerance, Body Composition and Blood Lipids in Obese African-American Woman Following Short-Term Training. The Journal of Sports Medicine and Physical Fitness, 38, 59-65.

Tamer, K. (1995). Sporda Fiziksel Fizyolojik Performansın Ölçülmesi ve Değerlendirilmesi, Türkerler Kitabevi, Ankara, 48-163. 
Taşgın, E., \& Dönmez, N. (2009). 10-16 yaş grubu çocuklara uygulanan egzersiz programının solunum parametreleri üzerine etkisi. Selçuk Üniversitesi Beden Eğitimi ve Spor Bilim Dergisi, 11(2), 1316.

Utter, A. C., Whitcomb, D. C., Nieman, D. C., Butterworth, D. E., \& Vermillion, S. S. (2000). Effects of Exercise Trainning on Gallbladder Function in An Obese Female Population. Medicine and Science in Sports and Exercise, 32(1), 41-45.

Wanger, J., Clausen, J. L., Coates, A., Pedersen, F., Brusasco, V., Burgos, F., Casaburi, R., Crapo, R., Enright, P., Grinten, P. M., Gustafsson, P., et al. (2005). Standardisation of the measurement of lung volumes. Eur Respir J, 26, 511-522.

Weinberger, S. E., \& Drazen, J. M. (1998). Disturbances of respiratory function. Harrison's Principles of Internal Medicine, 14th ed. McGraw-Hill, New York, 1407-19.

Williams, L. D., \& Morton A. R. (1986). Changes in selected cardiorespiratory responses to exercise and in body composition following a 12-week aerobic dance programme. J Sports Sci, 4,(3), 189199.

Yilmaz, T., \& Daglioglu, Ö. (2018). The Effect of Aerobic Training Program on Cardiopulmonary Parameters and Oxygen Saturation in Elite Judokas. Turkish Journal of Sport and Exercise, 20(3), 333-337.

Yüksel, O. (2003). Üniversitede Okuyan Erkek Öğrencilere Uygulanan Aerobik ve Anaerobik Egzersizlerin Dolaşım ve Solunum Sistemleri ile Vücut Yağ Oranları Üzerine Etkileri. Dumlupınar Üniversitesi, Sosyal Bilimler Enstitüsü, Kütahya.

\section{CITATION OF THIS ARTICLE}

İşleğen, G. \& Dağlığlu, Ö. (2020) The Effect of Aerobic Exercise on Pulmonary Function and Aerobic Capacity in Sedentary Men. International Journal of Sport, Exercise \& Training Sciences - IJSETS, 6(3), 80-87. DOI: $10.18826 /$ useeabd.784339 